\section{OPEN ACCESS}

Edited by:

Mark Alexander Lever,

ETH Zürich, Switzerland

Reviewed by:

Huiluo Cao,

The University of Hong Kong,

Hong Kong

Ida Helene Steen,

University of Bergen, Norway

*Correspondence:

Yi Zhang

zhangyizy128@126.com

Xiu-Lan Chen

cx10423@sdu.edu.cn

Specialty section:

This article was submitted to

Extreme Microbiology,

a section of the journal

Frontiers in Microbiology

Received: 18 December 2020 Accepted: 24 February 2021

Published: 16 March 2021

Citation

Cheng J-H, Wang $Y$, Zhang $X-Y$,

Sun $M-L$, Zhang $X$, Song $X-Y$,

Zhang $Y$-Z, Zhang $Y$ and Chen $X-L$

(2021) Characterization and Diversity Analysis of the Extracellular Proteases

of Thermophilic Anoxybacillus

caldiproteolyticus 1A02591 From

Deep-Sea Hydrothermal Vent

Sediment.

Front. Microbiol. 12:643508 doi: 10.3389/fmicb.2021.643508

\title{
Characterization and Diversity Analysis of the Extracellular Proteases of Thermophilic Anoxybacillus caldiproteolyticus 1A02591 From Deep-Sea Hydrothermal Vent Sediment
}

\begin{abstract}
Jun-Hui Cheng ${ }^{1}$, Yan Wang ${ }^{1}$, Xiao-Yu Zhang ${ }^{1}$, Mei-Ling Sun ${ }^{2,3}$, Xia Zhang ${ }^{4}$, Xiao-Yan Song 1,3, Yu-Zhong Zhang ${ }^{1,2,3}$, Yi Zhang ${ }^{1 *}$ and Xiu-Lan Chen ${ }^{1,3 *}$
\end{abstract}

' State Key Laboratory of Microbial Technology, Marine Biotechnology Research Center, Shandong University, Qingdao, China, ${ }^{2}$ College of Marine Life Sciences, and Frontiers Science Center for Deep Ocean Multispheres and Earth System, Ocean University of China, Qingdao, China, ${ }^{3}$ Laboratory for Marine Biology and Biotechnology, Qingdao National Laboratory for Marine Science and Technology, Qingdao, China, ${ }^{4}$ Department of Molecular Biology, Qingdao Vland Biotech Inc., Qingdao, China

Protease-producing bacteria play key roles in the degradation of marine organic nitrogen. Although some deep-sea bacteria are found to produce proteases, there has been no report on protease-secreting Anoxybacillus from marine hydrothermal vent regions. Here, we analyzed the diversity and functions of the proteases, especially the extracellular proteases, of Anoxybacillus caldiproteolyticus 1A02591, a proteasesecreting strain isolated from a deep-sea hydrothermal vent sediment of the East Pacific Ocean. Strain 1A02591 is a thermophilic bacterium with a strong protease-secreting ability, which displayed the maximum growth rate $\left(0.139 \mathrm{~h}^{-1}\right)$ and extracellular protease production $(307.99 \mathrm{U} / \mathrm{mL})$ at $55^{\circ} \mathrm{C}$. Strain $1 \mathrm{~A} 02591$ contains 75 putative proteases, including 65 intracellular proteases and 10 extracellular proteases according to signal peptide prediction. When strain 1A02591 was cultured with casein, 12 proteases were identified in the secretome, in which metalloproteases (6/12) and serine proteases (4/12) accounted for the majority, and a thermolysin-like protease of the M4 family was the most abundant, suggesting that strain 1A02591 mainly secreted a thermophilic metalloprotease. Correspondingly, the secreted proteases of strain 1A02591 showed the highest activity at the temperature as high as $70^{\circ} \mathrm{C}$, and was inhibited $70 \%$ by metalloprotease inhibitor 0 -phenanthroline and $50 \%$ by serine protease inhibitor phenylmethylsulfonyl fluoride. The secreted proteases could degrade different proteins, suggesting the role of strain 1A02591 in organic nitrogen degradation in deep-sea hydrothermal ecosystem. These results provide the first insight into the proteases of an Anoxybacillus strain from deep-sea hydrothermal ecosystem, which is helpful in understanding the function of Anoxybacillus in the marine biogeochemical cycle.

Keywords: protease-producing bacteria, thermophilic strain, Anoxybacillus, extracellular proteases, deep-sea hydrothermal ecosystem 


\section{INTRODUCTION}

Proteases, also called peptidases, account for approximately $2 \%$ of the total number of proteins in all types of organisms, which exert a variety of vital functions. Proteases are diverse, and a detailed classification of proteases is provided by the MEROPS database ${ }^{1}$, in which peptidases are divided into different clans and families (Barrett et al., 2001; Rawlings et al., 2008). Each peptidase is assigned to a family on the basis of statistically significant similarities in amino acid sequence, and homologous families are grouped together into a clan. Peptidases are totally divided into 7 groups based on the catalytic type, that is, aspartic peptidases (A), cysteine peptidases (C), metallo-peptidases (M), serine peptidases $(\mathrm{S})$, threonine peptidases $(\mathrm{T})$, mixed catalytic type $(\mathrm{M})$, and unknown type (U). Each group contains several clans and has an identifier as shown in the brackets. In addition, based on their location, microbial proteases are divided into intracellular proteases, which function inside a cell, and extracellular proteases, which are secreted and function in the periplasm or outside a cell. Microbial extracellular proteases not only provide carbon and nitrogen nutrients for microorganisms, but also play a crucial role in the degradation and recycling of environmental organic nitrogen on the earth (Ran et al., 2014; Li et al., 2016).

The genus Anoxybacillus was first proposed in 2000, members of which are characterized by their thermophilicity, Grampositive cell wall, and the formation of spores (Pikuta et al., 2000). So far, there are 23 species with validly published names in this genus, most of which are thermophiles isolated from terrestrial hot spring. Anoxybacillus strains are found to be able to secrete diverse thermophilic enzymes, including xylanase, cellulase, amylase, protease and other enzymes, which may have good industrial potentials (Bekler et al., 2016; Punam et al., 2018; Hajiabadi et al., 2019). Up to date, only a few proteases from Anoxybacillus have been reported. Lavrenteva et al. first reported two alkaliphilic and thermophilic Anoxybacillus strains secreted alkaline subtilisin-like serine proteinases (Lavrenteva et al., 2009). Later, a thermo-alkaline protease from Anoxybacillus sp. KP1 (Guven et al., 2015) and a thermostable alkaline protease SAPA secreted by A. kamchatkensis M1V (Mechri et al., 2019) were successively purified and characterized. The protease from Anoxybacillus sp. KP1 was stable at $50-60^{\circ} \mathrm{C}$ and $\mathrm{pH} 9.0$ for $1 \mathrm{~h}$, and was stable in the presence of detergents (Guven et al., 2015). The protease SAPA from A. kamchatkensis M1V was optimal at $70^{\circ} \mathrm{C}$ and $\mathrm{pH} 11$, and showed a high detergent compatibility and an outstanding stain removal capacity (Mechri et al., 2019). In addition, Nakamichi et al. reported that the thermophilic protease secreted by Anoxybacillus sp. MU3 may enhance the solubilization of sewage sludge (Nakamichi et al., 2010). These studies indicate that proteases from Anoxybacillus may have promising potentials in industry and biotechnology.

In addition to terrestrial hot spring, thermophiles are often found in marine hydrothermal ecosystem where proteasesecreting bacteria play important roles in the nitrogen cycling by decomposing dissolved and particulate organic nitrogen. Protease-secreting bacteria are often found in the diversity

${ }^{1}$ http://merops.sanger.ac.uk investigation of bacteria from hydrothermal vents. Sun et al. (2015) isolated 25 cultivable heterotrophic bacteria that exhibit extracellular protease activities from the sediments of two deep-sea hydrothermal vents of Okinawa Trough. Vitellibacter nionensis $\mathrm{VBW} 088^{\mathrm{T}}$ and Lutibacter profundi $\mathrm{LP} 1^{\mathrm{T}}$ isolated from hydrothermal vents were reported to be capable of degrading casein, indicating that they can secrete extracellular proteases (Rajasabapathy et al., 2015; Le Moine Bauer et al., 2016). In addition, based on metagenomic and metatranscriptomic sequencing on samples from deep-sea hydrothermal vent at Guaymas Basin, 59 genomes from 10 bacterial phyla contain multiple genes encoding extracellular peptidases, and 52 bacterial groups were detected to have transcripts for extracellular peptidases (Meng et al., 2016). Even so, studies on the proteolytic bacteria and their proteases from deep-sea hydrothermal vents are still quite limited. Until now, there has been no report on protease-secreting Anoxybacillus from marine hydrothermal vent regions.

In this study, we investigated the proteases of an Anoxybacillus strain, Anoxybacillus caldiproteolyticus 1A02591 (hereafter strain 1A02591), which was isolated from a deep-sea hydrothermal vent sediment of the East Pacific Ocean at a water depth of $2628 \mathrm{~m}$. Strain 1A02591 was a thermophilic bacterium with a strong protease-secreting ability. We characterized the extracellular proteases secreted by strain 1A02591, and analyzed the diversity and functions of the extracellular and intracellular proteases of strain $1 \mathrm{~A} 02591$ by genome sequencing and gene annotation. Moreover, the proteases secreted by strain 1A02591 cultured with casein were further identified by secretome analysis. The results showed that strain 1A02591 mainly secreted metalloproteases and serine proteases from different families, which are thermophilic and active toward different proteins, suggesting that strain 1A02591 may play an important role in the degradation and recycling of organic nitrogen in deep sea hydrothermal ecosystem.

\section{MATERIALS AND METHODS}

\section{Experimental Materials}

Anoxybacillus caldiproteolyticus 1A02591 (MCCC1A02591) was obtained from Marine Culture Collection of China (MCCC), which was isolated from the deep-sea sediment collected from the hydrothermal vent in the east of the Pacific Ocean $\left(12.71^{\circ} \mathrm{N}, 103.91^{\circ} \mathrm{W}\right)$. Casein and elastin were purchased from Sigma (United States). Insoluble type I collagen fiber (bovine achilles tendon) was purchased from Worthington Biochemical Co. (United States), gelatin from Boston Biomedical Inc. (United States), and casamino acids from Sangon Biotech Co., Ltd. (Shanghai, China).

\section{Analysis of the Optimum Temperature for Cell Growth and Extracellular Protease Production}

To determine the optimum temperature for cell growth, strain $1 \mathrm{~A} 02591$ was cultured at $45,50,55,60$, or $65^{\circ} \mathrm{C}$ in a liquid $2216 \mathrm{E}$ medium $(0.5 \%$ Bacto peptone, $0.1 \%$ yeast extract and 
artificial seawater, $\mathrm{pH}$ 7.5) in $50 \mathrm{~mL}$ Erlenmeyer fasks, which were controlled under the atmospheric pressure and constant agitation $(180 \mathrm{rpm})$. The $\mathrm{OD}_{600}$ of the cultures was monitored at an interval of $2 \mathrm{~h}$. The growth rate of strain $1 \mathrm{~A} 02591$ was measured by the increment of $\mathrm{OD}_{600}$ per hour at each temperature and was analyzed by DMfit v3.5 using Gompertz model (Baranyi and Roberts, 1994; Dey et al., 2020). To determine the optimum temperature for extracellular protease production, strain $1 \mathrm{~A} 02591$ was cultured at $45,50,55,60$, or $65^{\circ} \mathrm{C}$ in $50 \mathrm{~mL}$ fermentation medium $(0.3 \%$ casein, $0.2 \%$ yeast extract and artificial seawater, pH 7.5) in $500 \mathrm{~mL}$ Erlenmeyer fasks, which were controlled under the atmospheric pressure and constant agitation $(180 \mathrm{rpm})$. The activity of the extracellular protease in the cultures was measured with casein as substrate at an interval of $24 \mathrm{~h}$.

\section{Enzyme Assay}

The activity of the protease toward casein was measured by the Folin-phenol method as previously described (Chen et al., 2003). Briefly, a reaction mixture of $100 \mu \mathrm{L}$ enzyme in $50 \mathrm{mM}$ Tris$\mathrm{HCl}(\mathrm{pH} 7.5)$ and $100 \mu \mathrm{L}$ of $2 \%(\mathrm{w} / \mathrm{v})$ casein was incubated at $70^{\circ} \mathrm{C}$ for $10 \mathrm{~min}$. After incubation, the reaction was stopped by adding $200 \mu \mathrm{L}$ trichloroacetic acid $(0.4 \mathrm{M})$ into the mixture. Then, $100 \mu \mathrm{L}$ of the supernatant of the reaction mixture was incubated with $500 \mu \mathrm{L}$ of sodium carbonate solution $(0.4 \mathrm{M})$ and $100 \mu \mathrm{L}$ of the Folin-phenol reagent at $40^{\circ} \mathrm{C}$ for $20 \mathrm{~min}$. After incubation, the $\mathrm{OD}_{660}$ of the mixture was measured. One unit of enzyme activity (U) is defined as the amount of enzyme that released $1 \mu \mathrm{g}$ tyrosine from casein per min. The activities of the protease toward collagen and gelatin were assayed by the methods described by Li et al. (2016). For collagen, $5 \mathrm{mg}$ collagen was incubated with $1 \mathrm{~mL}$ enzyme solution with continuous stirring at $70^{\circ} \mathrm{C}$ for $5 \mathrm{~h}$. One unit of enzyme activity (U) is defined as the amount of enzyme that released $1 \mu \mathrm{mol}$ leucine from collagen per hour. For gelatin, the mixture of $100 \mu \mathrm{L}$ enzyme solution and $100 \mu \mathrm{L}$ of $2 \%(\mathrm{w} / \mathrm{v})$ gelatin was incubated at $70^{\circ} \mathrm{C}$ for $10 \mathrm{~min}$. One unit of enzyme activity (U) is defined as the amount of enzyme that released $1 \mu \mathrm{mol}$ of leucine from gelatin per hour. The activity of the protease toward elastin was determined by the photometric method (Sachar et al., 1955). The enzyme was incubated with $5 \mathrm{mg}$ elastin-orcein in $50 \mathrm{mM}$ Tris- $\mathrm{HCl}$ ( $\mathrm{pH} 7.5$ ) at $70^{\circ} \mathrm{C}$ for $1 \mathrm{~h}$, and then the residual elastin-orcein was removed by centrifugation. The $\mathrm{OD}_{590}$ of the supernatant was measured. One unit of enzyme activity is defined as the amount of enzyme that released $1 \mathrm{nmol}$ orcein per min.

\section{Characterization of the Extracellular Protease}

The optimal temperature of the protease was determined by assaying the enzyme activity at $\mathrm{pH} 7.5$ from 0 to $100^{\circ} \mathrm{C}$. To evaluate the effect of temperature on the protease stability, the residual activity was measured at $70^{\circ} \mathrm{C}$ and $\mathrm{pH} 7.5$ after the protease was incubated at 60,70 , or $80^{\circ} \mathrm{C}$ for different time intervals $(15,30,45,60,75$, or $90 \mathrm{~min})$. The optimum $\mathrm{pH}$ of the protease was evaluated by assaying the enzyme activity at $70^{\circ} \mathrm{C}$ in the Britton-Robinson buffers at $\mathrm{pH}$ values ranging from 3 to 11 (Chaberek et al., 1952). The effect of $\mathrm{NaCl}$ concentration on enzyme activity was determined by assaying the enzyme activity at $70^{\circ} \mathrm{C}$ and $\mathrm{pH} 7.5$ with $\mathrm{NaCl}$ of different concentrations from 0 to $4 \mathrm{M}$ in the reaction mixture. The effects of metal ions $\left(\mathrm{Li}^{+}, \mathrm{K}^{+}, \mathrm{Ca}^{2+}, \mathrm{Mg}^{2+}, \mathrm{Cu}^{2+}, \mathrm{Ni}^{2+}, \mathrm{Mn}^{2+}\right.$, $\mathrm{Ba}^{2+}, \mathrm{Fe}^{2+}, \mathrm{Zn}^{2+}, \mathrm{Sr}^{2+}, \mathrm{Co}^{2+}$ and $\left.\mathrm{Sn}^{2+}\right)$ and protease inhibitors PMSF (phenylmethylsulfonyl fluoride), EDTA (ethylene diamine tetraacetic acid), EGTA (ethylene glycol tetraacetic acid), and $o$-P (o-phenanthroline) on the extracellular protease were evaluated by measuring the enzyme activity at $70^{\circ} \mathrm{C}$ and $\mathrm{pH} 7.5$ after the enzyme was pre-incubated with each metal ion or inhibitor for $1 \mathrm{~h}$ at $4^{\circ} \mathrm{C}$. The substrate specificity of the extracellular protease was analyzed by measuring its activities toward casein, gelatin, collagen (Bovine insoluble type I collagen fiber) and elastin.

\section{Genome Sequencing and Analysis}

The genome of strain 1A02591 was sequenced by an Illumina hiseq2000 sequencer in Shanghai Majorbio Bio-pharm Biotechnology Co., Ltd., Shanghai, China. ABySS v2.0.2 was used to do genome assembly with default parameters (with $1=15$ ) to obtain the optimal results of the assembly (Jackman et al., 2017). GapCloser v1.12 was subsequently applied to fill up the remaining local inner gaps and to correct the single base polymorphism for the final assembly results. Ab initio prediction method was used to obtain gene models with Glimmer v3.02 (Delcher et al., 2007). Gene functions were annotated by Blastp using Swiss-Prot ${ }^{2}$, COG (Clusters of Orthologous Groups ${ }^{3}$ ) and KEGG (Kyoto Encyclopedia of Genes and Genomes ${ }^{4}$ ) (Tatusov et al., 2000; Minoru et al., 2016). tRNAs were identified using the tRNAscan-SE $\left(\mathrm{v} 1.23^{5}\right)$ and rRNAs were determined using the RNAmmer (v1.26) (Lowe and Eddy, 1997; Karin et al., 2007). The obtained genome sequence was deposited in GenBank under the accession number JAEILW000000000. The signal peptides of the proteases were predicted by using SignalP ${ }^{7}$ (Bendtsen et al., 2004). The peptidase families were analyzed by Blastp searching against the MEROPS peptidase database Release $11.0^{8}$ (Rawlings et al., 2008, 2017). The amino acid sequences of peptidases were entered via the blast merops with a cutoff E-value of 1e-5.

\section{Secretome Analysis}

Strain $1 \mathrm{~A} 02591$ was cultured at $55^{\circ} \mathrm{C}$ for $12 \mathrm{~h}$ in the casein medium $(0.3 \%$ casein, $0.2 \%$ yeast extract and artificial seawater, $\mathrm{pH} 7.5)$. Then, the culture was centrifuged $(10,000 \mathrm{rpm}$ for $20 \mathrm{~min}$ at $4^{\circ} \mathrm{C}$ ) and the supernatant was collected. Proteins in the supernatant was precipitated by $50 \mathrm{~mL}$ acetone solution containing $10 \%$ trichloroacetic acid and $0.1 \%$ dithiothreitol overnight at $-20^{\circ} \mathrm{C}$. The precipitates were harvested by centrifugation for $20 \mathrm{~min}$ at $8,000 \mathrm{rpm}$ and $4^{\circ} \mathrm{C}$, washed

\footnotetext{
${ }^{2}$ http://uniprot.org

${ }^{3}$ http://www.ncbi.nlm.nih.gov/COG

${ }^{4}$ http://www.genome.jp/kegg/

${ }^{5}$ http://lowelab.ucsc.edu/tRNAscan-SE

${ }^{6}$ http://www.cbs.dtu.dk/services/RNAmmer/

${ }^{7}$ http://www.cbs.dtu.dk/services/SignalP/

${ }^{8}$ https://www.ebi.ac.uk/merops/
} 

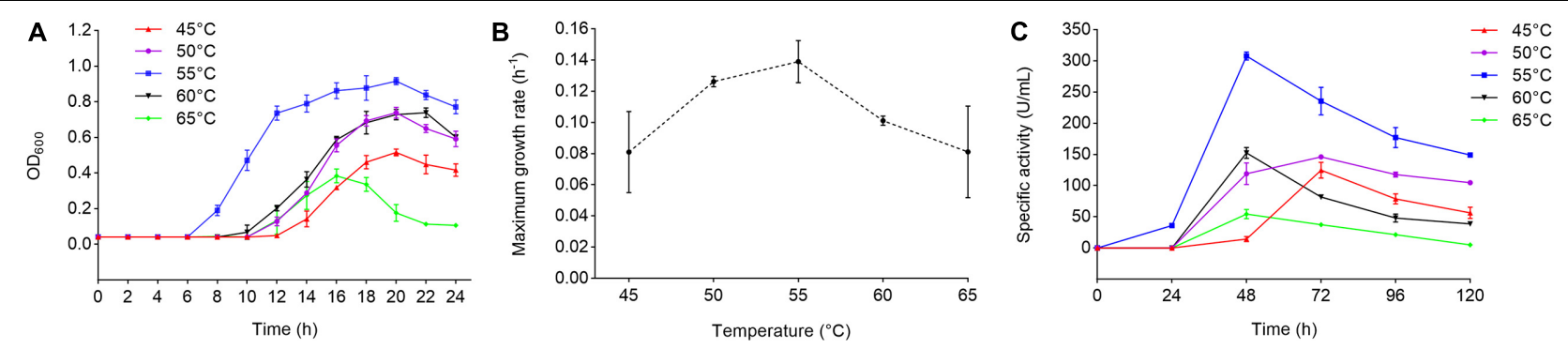

FIGURE 1 | Growth and protease production of strain $1 \mathrm{~A} 02591$ at different temperatures. (A) Growth curves of strain $1 \mathrm{~A} 02591$ at temperatures from $45^{\circ} \mathrm{C}$ to $65^{\circ} \mathrm{C}$. Strain 1A02591 was cultured in liquid 2216E medium at pH 7.5 and cell growth was monitored by measuring the $\mathrm{OD}_{600}$ of the culture. (B) Maximum specific growth rate of strain $1 \mathrm{A0} 2591$ at $45,50,55,60$, and $65^{\circ} \mathrm{C}$. The growth rate of strain $1 \mathrm{~A} 02591$ was measured by the increment of $\mathrm{OD}_{600}$ per hour at each temperature and was fitted by DMfit v3.5 using Gompertz model. (C) The extracellular protease production of strain $1 \mathrm{~A} 02591$ cultured at temperatures from $45^{\circ} \mathrm{C}$ to $65^{\circ} \mathrm{C}$. Strain 1 A02591 was cultured in a fermentation medium as described in section "MATERIALS AND METHODS," and the protease activity in the culture was measured at $70^{\circ} \mathrm{C}$ with casein as the substrate. The graphs show data from triplicate experiments (mean \pm SD).

sequentially by $80 \%$ acetone solution and $100 \%$ acetone solution, and then were dried. Subsequently, the sample was denatured by a denaturation buffer $(0.5 \mathrm{M}$ Tris- $\mathrm{HCl}, 2.75 \mathrm{mM}$ EDTA, $6 \mathrm{M}$ Guanadine- $\mathrm{HCl}$ ), reduced by $1 \mathrm{M}$ dithiothreitol, alkylated by $1 \mathrm{M}$ iodoacetamide and digested by trypsin. Peptides in the sample were trapped and desalted on the enrichment column (ZipTip C18, Millipore) using 50\% acetonitrile/ $\mathrm{H}_{2} \mathrm{O}$ containing $0.1 \%$ trifluoroethanoicacid as the eluent. MS spectra of the sample were automatically recorded by the mass spectrometer Orbitrap Elite (ThermoFisher Scientific, Bremen, Germany) coupled online to an Easy-nLC 1000 (Thermo Fisher Scientific, Bremen, Germany). Finally, Thermo Scientific Proteome Discoverer ${ }^{\mathrm{TM}}$ software version 1.4 was used as the research tool to analyze the secreted proteins. The secretome data was uploaded to the ProteomeXchange Consortium via the PRIDE under the accession number PXD023396.

\section{RESULTS}

\section{A. caldiproteolyticus $1 \mathrm{~A} 02591$ Is a Protease-Secreting Thermophilic Bacterium}

Strain 1A02591 was isolated as a protease-producing bacterium from the deep-sea sediment of the hydrothermal vent in the East Pacific Ocean, and preserved in MCCC. To further characterize strain 1A02591, we analyzed the optimum temperatures for its growth and for its extracellular protease production. We speculated that strain 1A02591 was likely thermophilic based on its hydrothermal origion. Thus, strain 1A02591 was cultured at $45,50,55,60$, and $65^{\circ} \mathrm{C}$ to determine the optimum temperatures for its growth and for its extracellular protease production. When cultured in 2216E medium, the strain 1A02591 showed the best growth and the highest growth rate at $55^{\circ} \mathrm{C}$ (Figures 1A,B). When strain $1 \mathrm{~A} 02591$ was cultured with casein as the carbon and nitrogen source, the extracellular protease production at $55^{\circ} \mathrm{C}$ was higher than those at the other temperatures, and reached the highest (307.99 U/mL) after $48 \mathrm{~h}$ culturation (Figure 1C). Therefore, strain $1 \mathrm{~A} 02591$ is a protease-secreting thermophilic bacterium with an optimum temperature of $55^{\circ} \mathrm{C}$ for its growth and extracellular protease production.

\section{Characterization of the Extracellular Proteases Secreted by Strain 1A02591}

We further characterized the extracellular proteases secreted by strain 1A02591 cultured with casein in the medium. When the protease activity in the culture of strain 1A02591 reached the highest, the supernatant of the culture was collected and used for extracellular proteases characterization. The extracellular proteases showed the highest activity at $70^{\circ} \mathrm{C}$ and kept $37.9 \%$ of the highest activity at $100^{\circ} \mathrm{C}$ (Figure 2A), indicating that the extracellular proteases were thermophilic. The secreted proteases retained approximately $70 \%$ of its activity at $60^{\circ} \mathrm{C}$ and $50 \%$ at $70^{\circ} \mathrm{C}$ after incubation for $90 \mathrm{~min}$ (Figure 2B). The half-life time of the secreted proteases at $80^{\circ} \mathrm{C}$ was approximately $10 \mathrm{~min}$. The activity of the extracellular proteases toward casein were detectable over a broad range from $\mathrm{pH} 3$ to 11 with a maximal activity at $\mathrm{pH} 7$ (Figure 2C). The proteases retained $89 \%$ activity in the Tris- $\mathrm{HCl}$ buffer containing $0.5 \mathrm{M} \mathrm{NaCl}$, and $29 \%$ activity in the buffer containing $4 \mathrm{M} \mathrm{NaCl}$ (Figure 2D). Altogether, these results indicate that the proteases secreted by strain 1A02591 are thermophilic and neutral, with relatively good thermostability and salt-tolerance.

To determine the substrate specificity of the extracellular proteases of strain 1A02591, the activities of the extracellular proteases toward casein, gelatin, bovine insolute type I collagen fiber and elastin at $70^{\circ} \mathrm{C}$ were determined. As shown in Table 1, the extracellular proteases of strain 1A02591 could hydrolyze casein, gelatin and bovine insoluble type I collagen fiber, but not elastin.

To ascertain the type of the extracellular proteases of strain 1A02591, we analyzed the effects of protease inhibitors on the protease activity by measuring the residue activity after the secreted proteases were pre-incubated with protease inhibitor for $1 \mathrm{~h}$. The protease activity was almost totally inhibited by EGTA and approximately $70 \%$ protease activity was inhibited by $o$-p (a specific inhibitor of metalloproteinase) (Table 2), 


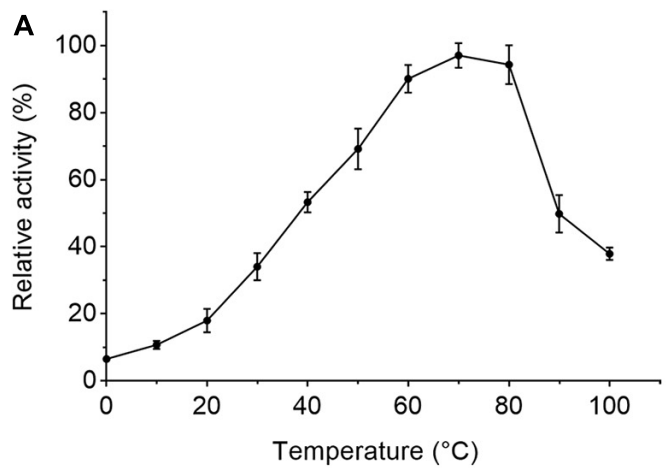

C

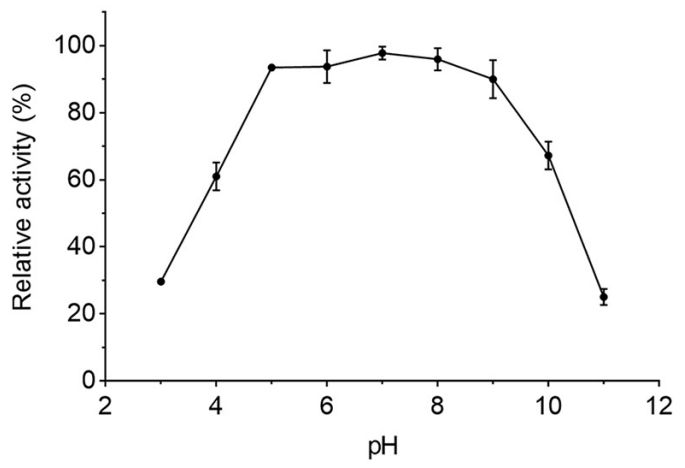

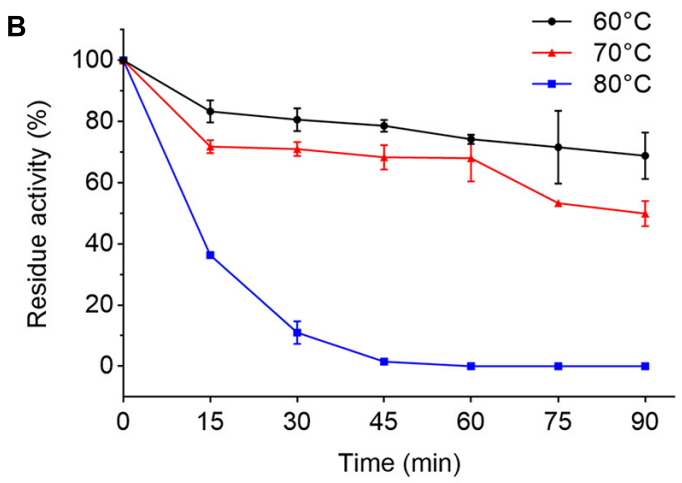

D

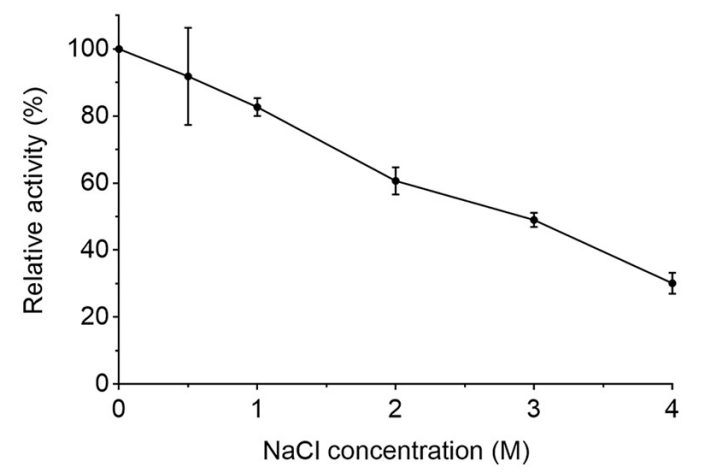

FIGURE 2 | Characterization of the extracellular protease of strain 1A02591. (A) Effect of temperature on the protease activity. The protease activity was measured in $50 \mathrm{mM}$ Tris- $\mathrm{HCl}$ buffer $\left(\mathrm{pH} \mathrm{7.5)}\right.$ from $0^{\circ} \mathrm{C}$ to $100^{\circ} \mathrm{C}$. (B) Effect of temperature on the protease stability. The residue activity of the protease was measured after the protease was incubated at 60,70 , or $80^{\circ} \mathrm{C}$ for different times. (C) Effect of $\mathrm{pH}$ on the protease activity. The protease activity was determined at $70^{\circ} \mathrm{C}$ in Britton-Robinson buffers at $\mathrm{pH}$ values ranging from 3 to 11 . (D) Effect of $\mathrm{NaCl}$ concentration on the protease activity. The protease activity was determined at $70^{\circ} \mathrm{C}$ with a $\mathrm{NaCl}$ concentration from 0 to $4 \mathrm{M}$. The graphs show data from triplicate experiments (mean $\pm \mathrm{SD}$ ).

which indicated that metallopeptidase(s) was dominant in the extracellular proteases of strain 1A02591. In addition, 50\% protease activity was inhibited by PMSF (Table 2), a specific inhibitor of serineprotease, suggesting that strain 1A02591 also secreted serine protease(s).

The effects of metal ions on the activity of the extracellular proteases of strain 1A02591 were also investigated. Among the thirteen metal ions tested, $\mathrm{Ni}^{2+}, \mathrm{Cu}^{2+}, \mathrm{Fe}^{2+}, \mathrm{Co}^{2+}$, and $\mathrm{Zn}^{2+}$ all had an inhibitory effect on the protease activity at $2 \mathrm{mM}$, and only $2 \mathrm{mM} \mathrm{Mn}^{2+}$ increased the protease activity by 1.2 folds (Table 2).

Taken together, these results indicated that when cultured with casein in the medium, strain 1A02591 secreted thermophilic neutral proteases that may include dominant metalloprotease(s) and serine protease(s).

TABLE 1 | The substrate specificity of the extracellular protease of strain 1A02591.

\begin{tabular}{lc}
\hline Substrate & Activity (U/mL) \\
\hline Casein & $398.03 \pm 8.14$ \\
Bovine insoluble type I collagen fiber & $76.61 \pm 7.28$ \\
Gelatin & $539.24 \pm 24.92$ \\
Elastin-orcein & $N D$ \\
\hline The data represent the mean \pm SD of three experimental repeats. ND means that \\
the enzyme activity was not detectable.
\end{tabular}

\section{Diversity and Function Analyses of the Proteases of Strain 1A02591 by Genome Sequencing and Gene Annotation}

Next, we set out to analyze the diversity of the proteases of strain $1 \mathrm{~A} 02591$ and their functions. First, we sequenced the genome DNA of strain 1A02591, and found out all putative proteases by gene annotation. Strain 1 A02591 contains 75 proteases, which fall in 22 families of metalloprotease peptidases, 11 families of serine peptidases, 5 families of cysteine peptidases, 4 families of aspartic peptidases, 1 family of threonine peptidase and 1 family of peptidase of unknown catalytic type (Figure 3). Based on signal peptide prediction, 10 proteases have a predicted signal peptide, which are regarded as extracellular proteases. The other 65 proteases without a predicted signal peptide are regarded as intracellular proteases.

Based on the KEGG pathway annotation, the metabolic pathways of strain 1A02591 were analyzed, particularly the pathways involving genes encoding proteases. KEGG analysis revealed that 2063 proteins are involved in different pathways, and the top 20 metabolic pathways according to the number of involved proteins are shown in Figure 4. Proteins involved in carbohydrate metabolism (407/2063) are the most, followed by those involved in amino acid metabolism (303/2063). It 
TABLE 2 | Effects of metal ions and inhibitors on activity of the protease of strain 1A02591.

\begin{tabular}{|c|c|c|c|c|c|}
\hline Metal ion (2 mM) & Relative activity ${ }^{\mathrm{a}}(\%)$ & Metal ion (2 mM) & Relative activity $^{\mathrm{a}}(\%)$ & Inhibitors $^{\mathrm{b}}$ (2 mM) & Residual activity $^{\mathrm{c}}(\%)$ \\
\hline Control & 100.00 & $\mathrm{Mn}^{2+}$ & $120.22 \pm 7.59$ & Control & 100.00 \\
\hline $\mathrm{Ca}^{2+}$ & $99.11 \pm 5.18$ & $\mathrm{Ba}^{2+}$ & $98.55 \pm 0.17$ & PMSF & $54.54 \pm 2.55$ \\
\hline $\mathrm{Li}^{+}$ & $104.86 \pm 7.21$ & $\mathrm{Fe}^{2+}$ & $76.79 \pm 3.41$ & EDTA & $51.42 \pm 3.59$ \\
\hline $\mathrm{K}^{+}$ & $97.80 \pm 2.05$ & $\mathrm{Zn}^{2+}$ & $83.20 \pm 3.52$ & EGTA & ND \\
\hline $\mathrm{Mg}^{2+}$ & $96.02 \pm 1.90$ & $\mathrm{Sr}^{2+}$ & $102.17 \pm 1.70$ & $O-P$ & $31.99 \pm 2.67$ \\
\hline $\mathrm{Cu}^{2+}$ & $72.32 \pm 6.46$ & $\mathrm{Co}^{2+}$ & $85.87 \pm 4.31$ & & \\
\hline $\mathrm{Ni}^{2+}$ & $57.14 \pm 3.21$ & $\mathrm{Sn}^{2+}$ & $101.87 \pm 1.79$ & & \\
\hline
\end{tabular}

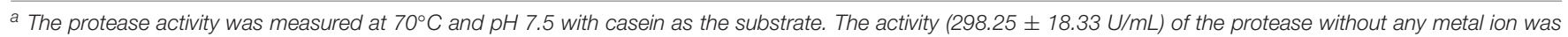
used as a control (100\%).

b PMSF, phenylmethylsulfonyl fluoride; EDTA, ethylene diamine tetraacetic acid; EGTA, ethylene glycol tetraacetic acid; o-P, o-phenanthroline.

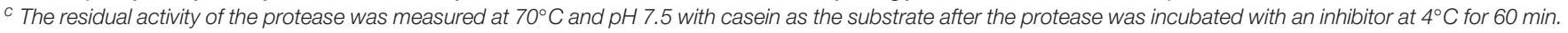

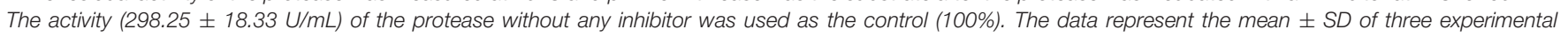
repeats. ND means that the enzyme activity was not detectable.

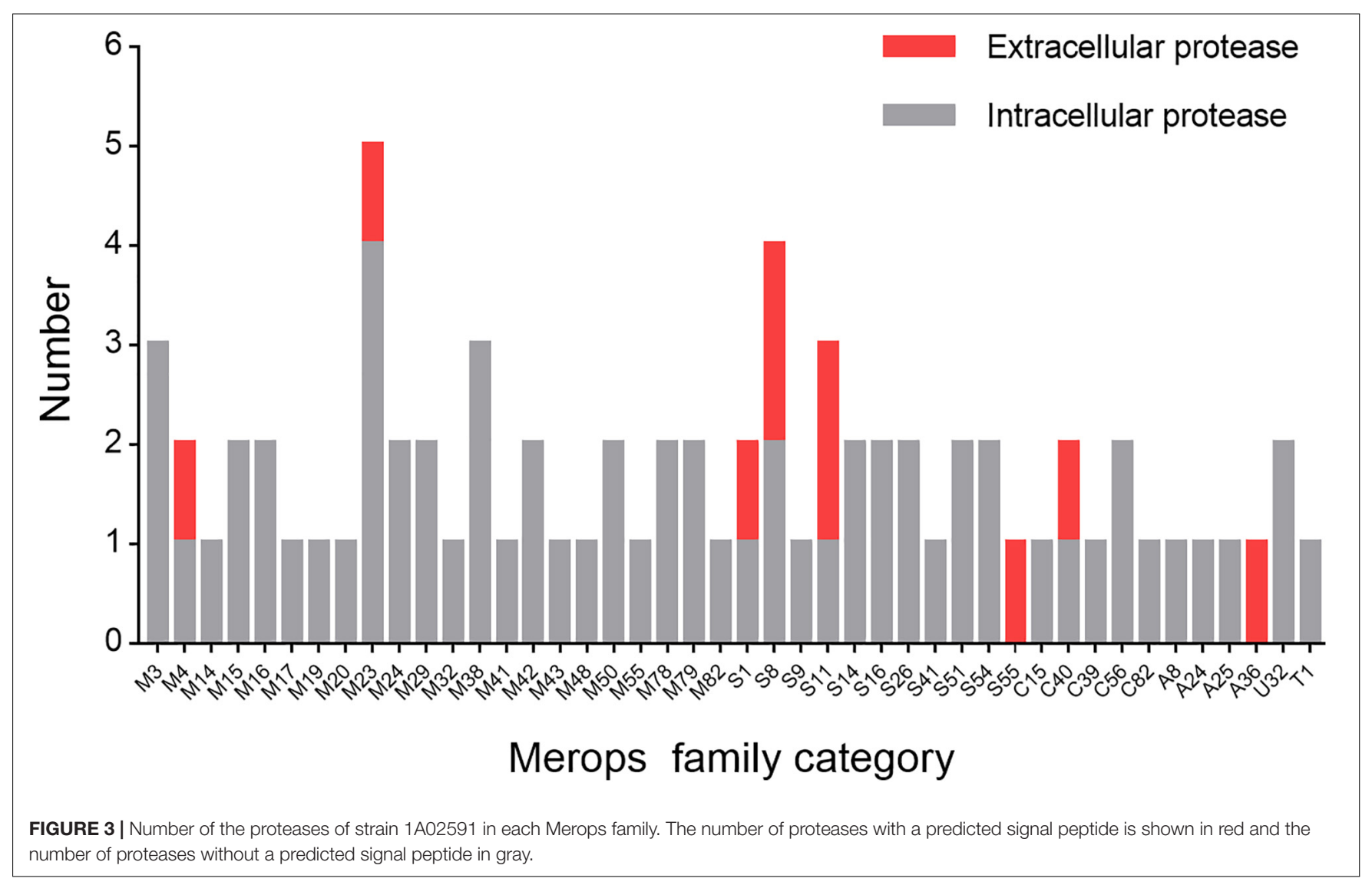

is worth noting that 10 proteases take part in 7 kinds of KEGG pathways, including carbohydrate metabolism (k01179), amino acid metabolism (k01439), metabolism of other amino acids (k01255), signal transduction (k01179), glycan biosynthesis and metabolism (K07258), folding, sorting and degradation (k03100 and k03101), and cell growth and death (k01338, $\mathrm{k} 01358$ and $\mathrm{k} 11749$ ).

As shown in Figure 3, the 65 putative intracellular proteases of strain 1A02591 are distributed in 42 families of proteases. It has been reported that intracellular proteases play essential roles in various cell processes and pathways (Gottesman, 1996). Based on
COG database, the functions of the 65 intracellular proteases of strain 1A02591 are classified into 8 categories: posttranslational modification (protein turnover, chaperones) (15/65); amino acid transport and metabolism (17/65); translation (ribosomal structure and biogenesis) (1/65); cell wall/membrane/envelope biogenesis (12/65); cell motility (1/65); intracellular trafficking, secretion and vesicular transport (4/65); general function prediction only (10/65); and unknown function (7/65) (Figure 5). Thus, a majority of intracellular proteases are involved in amino acid transport and metabolism, posttranslational modification and cell wall/membrane/envelope biogenesis in strain 1A02591. 

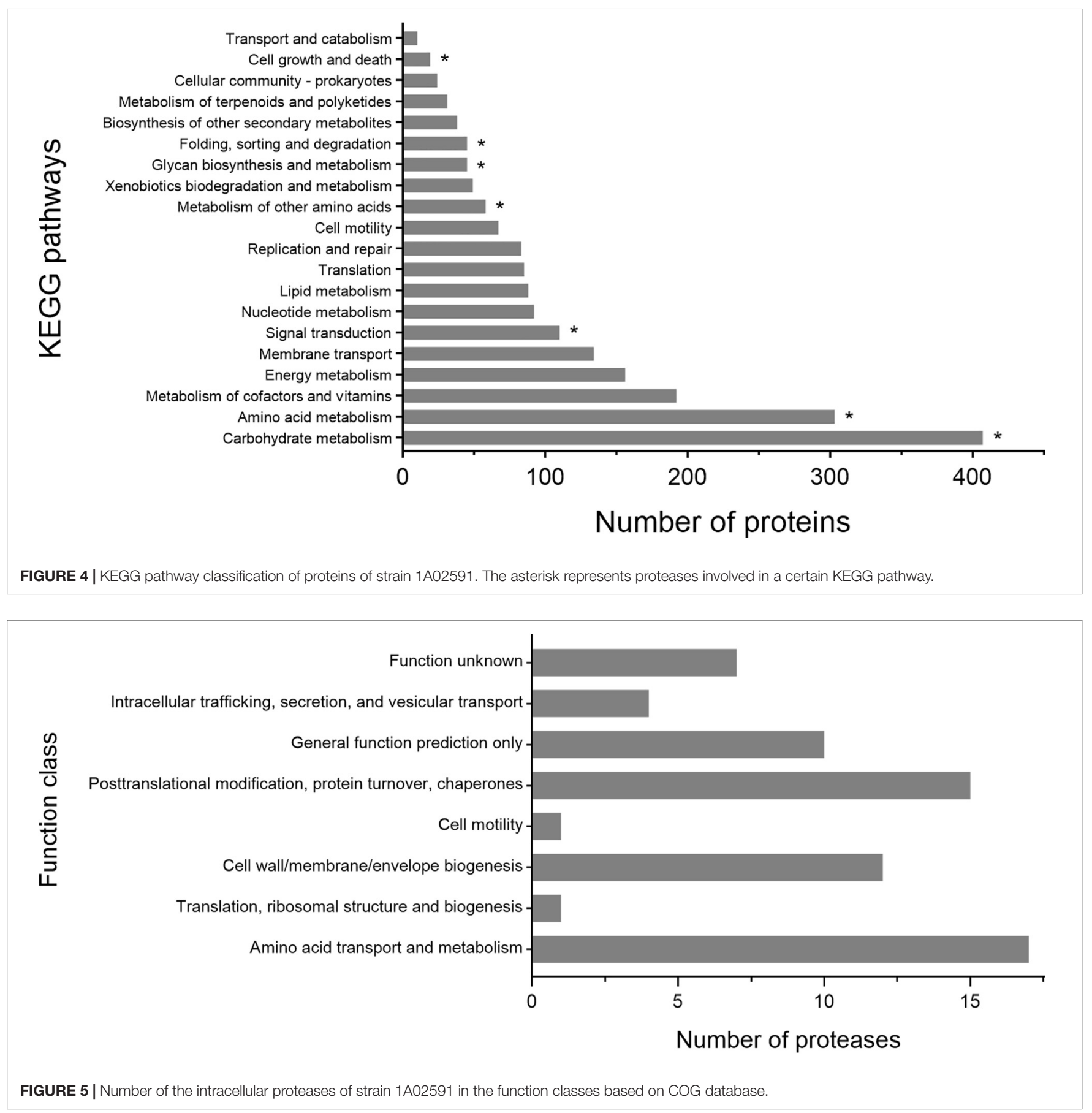

The predicted functions of these intracellular proteases are shown in Supplementary Table 1.

As shown in Figure 3, the 10 putative extracellular proteases are distributed in 8 families including 1 thermostable neutral proteinase of M4, 1 SpoIVB peptidase of S55, 1 peptidase of C40, 2 D-alanyl-D-alanine carboxypeptidases of S11, 1 sigmaE processing peptidase SpoIIGA of A36, 1 S1 peptidase, 1 M23 peptidase, and 2 S8 peptidases. Among them, the 2 proteases from families A36 and S55 are likely involved in sporulation and the development of spores (Dong and Cutting, 2004; Junne et al., 2011), the S11 proteases are likely involved in cell wall reconstruction, and the other 6 proteases from families M4, M23, S1, S8 and C40 are all likely involved in the degradation of extracellular proteins and peptides for the strain nutrition (Laskar et al., 2012; Zhao et al., 2019). Especially, the S8 proteases may have the ability to degrade collagen from animals (Ran et al., 2013), and the M23 and C40 proteases may have ability to degrade peptidoglycan from bacterial cell wall (Fukushima et al., 2018; Tang et al., 2020). The possible functions of the extracellular proteases of strain 1A02591 are detailedly shown in Table 3. 
TABLE 3 | The extracellular proteases of strain 1A02591 predicted by genome sequencing and gene annotation.

\begin{tabular}{|c|c|c|c|}
\hline Gene ID & Family & Protease & Predicted functions \\
\hline orf00069 & M4 & Thermostable neutral proteinase & $\begin{array}{l}\text { Degrades extracellular proteins and peptides for bacterial nutrition; } \\
\text { thermolysin-like protease }\end{array}$ \\
\hline orf00545 & S55 & SpolVB peptidase & Essential for the proper development of spores \\
\hline orf00831 & C40 & Peptidase P60 & Responsible for the degradation of bacterial cell wall components \\
\hline orf01043 orf03925 & S11 & D-alanyl-D-alanine carboxypeptidase & $\begin{array}{l}\text { Synthesis of bacterial cell walls, cleaving the D-Ala-D-Ala crosslinks in the cell } \\
\text { wall peptidoglycans }\end{array}$ \\
\hline orf01198 & A36 & Sigma-E processing peptidase SpollGA & Involved in sporulation \\
\hline orf02124 & S1 & Peptidase S1 & Heat shock protein that combines refolding and proteolytic activities \\
\hline orf02670 & M23 & M23 family peptidase & Lyses cell walls of other bacteria, either as a defensive or feeding mechanism \\
\hline orf03156 & S8 & Peptidase S8 & Some function at extreme temperatures, and others at high or low $\mathrm{pH}$ values \\
\hline orf03370 & S8 & Serine protease & Involved in nutrition \\
\hline
\end{tabular}

TABLE 4 | The extracellular proteases secreted by strain 1A02591 identified by secretome analysis.

\begin{tabular}{|c|c|c|c|c|c|}
\hline Gene ID & Family & Protease & PSMs & Abundance $^{a}$ & Biological functions \\
\hline orf00069 & M4 & Thermostable neutral proteinase & 50 & $15.72 \%$ & $\begin{array}{l}\text { Degrades extracellular proteins and peptides for bacterial nutrition; } \\
\text { thermolysin-like protease }\end{array}$ \\
\hline orf04095 & S8 & Serine protease & 46 & $14.47 \%$ & Thermostable peptidase \\
\hline orf02484 & M3 & M3 family & 46 & $14.47 \%$ & Degradation of oligopeptides \\
\hline orf02323 & M3 & Oligoendopeptidase F & 37 & $11.64 \%$ & Degradation of oligopeptides \\
\hline orf03925 & $\mathrm{S} 11$ & D-alanyl-D-alanine carboxypeptidase & 31 & $9.75 \%$ & $\begin{array}{l}\text { Synthesis of bacterial cell walls, cleaving the D-Ala-D-Ala crosslinks in the cell } \\
\text { wall peptidoglycans }\end{array}$ \\
\hline orf00077 & M20 & Dipeptidase PepV & 30 & $9.43 \%$ & $\begin{array}{l}\text { Hydrolyses the late products of protein degradation so as to complete the } \\
\text { conversion of proteins to free amino acids }\end{array}$ \\
\hline orf03187 & M32 & Carboxypeptidase M32 & 24 & $7.55 \%$ & Stable up to high temperatures \\
\hline orf00831 & $\mathrm{C} 40$ & Peptidase P60 & 23 & $7.23 \%$ & Responsible for the degradation of bacterial cell wall components \\
\hline orfO2670 & M23 & M23 family peptidase & 12 & $3.77 \%$ & Lyses cell walls of other bacteria, either as a defensive or feeding mechanism \\
\hline orf03370 & S8 & Serine protease & 10 & $3.14 \%$ & Thermostable peptidases \\
\hline orf02654 & S41 & Peptidase S41 & 7 & $2.20 \%$ & C-terminal processing peptidase \\
\hline orf03626 & C40 & Peptidase P60 & 2 & $0.63 \%$ & Responsible for the degradation of bacterial cell wall components \\
\hline
\end{tabular}

a Abundance was calculated based on the proportion of the PSMs of a protease in the sum of PSMs of all proteases in the secretome.

\section{Identification of the Proteases Secreted by Strain 1 A02591 by Secretome Analysis}

In order to ascertain the secreted proteases, strain 1A02591 was cultured with casein in the medium, and the secretome at the 12th $\mathrm{h}$ of cultivation was analyzed. Finally, a total of 12 proteases were found in the secretome, including 6 metalloproteases (distributed in M3, M4, M20, M23, and M32), 4 serine proteases (distributed in S8, S11, and S41), 1 cysteine protease of C40 and 1 mixed type protease of C40 (Table 4). Among them, metalloproteases were the most in both number (6/12) and abundance (62.58\%), followed by serine proteases with a total abundance of $29.56 \%$. These data were consistent with the above inhibitor experiment result that indicated that the secreted proteases of strain $1 \mathrm{~A} 02591$ contained dominant metalloproteases and serine proteases (Table 2). Among the secreted proteases, the M4 protease was the most abundant, which has $99.82 \%$ sequence identity with thermolysin, the prototype of the M4 family, suggesting that this thermolysin-like protease secreted by strain 1A02591 is likely thermophilic, because thermolysin is a known thermophilic protease. This is consistent with the above biochemical result that the secreted proteases of strain 1A02591 were thermophilic
(Figure 2A). Because proteases from families M4 and S8 all have caseinolytic activity and gelatinolytic activity (Li et al., 2016; Wang et al., 2020), the secreted proteases from these families likely contributed to the significant caseinolytic activity and gelatinolytic activity in the culture of strain 1A02591 as shown in Table 1.

In addition, we noticed that among the 12 secreted proteases, only 5 have a predicted signal peptide, that is, $1 \mathrm{M} 4$ protease, 1 S8 protease, 1 S11 protease, 1 C40 protease, and 1 M23 protease, which are likely secreted by signal peptide-mediated translocation. The other 7 secreted proteases without a predicted signal peptide might be secreted outside the cell via other secretion systems, such as the twin-arginine transport pathway, or a non-classical secretory system (Karched et al., 2019). As shown in Table 3, there are 10 putative proteases with a predicted signal peptide in strain 1A02591. Thus, in addition to the 5 ones identified by secretome analysis, 5 putative proteases with a predicted signal peptide were not found by secretome analysis, probably because these proteases were not expressed or their secretion amounts were too small to be detected in secretome analysis when strain 1A02591 was cultured with casein. 


\section{DISCUSSION}

There is a unique light-independent ecosystem in deep-sea hydrothermal vents, where the biogroup mainly contains chemoautotrophic and heterotrophic prokaryotes and animals such as worms, mussels and shrimps (Edwards and Nelson, 1991; Plouviez et al., 2013; Kim et al., 2015). While chemoautotrophic prokaryotes produce organic molecules with energy by oxidizing the inorganic compounds available in the environments, heterotrophic prokaryotes are actively involved in carbon and nitrogen cycling by decomposing dissolved and particulate organic materials in the deep-sea hydrothermal ecosystem. Several studies have shown that protease-producing microorganisms are present in deep-sea hydrothermal ecosystem, suggesting that they are important players in the decomposition of dissolved and particulate organic nitrogen (Ladrat et al., 1995; Pikuta et al., 2007). Burrell et al. reported that extracellular protease activity was detected in the vent water bacterial community, indicating the presence of proteolytic bacteria in the hydrothermal vent of north New Zealand (Burrell et al., 2015). Sun et al. (2015) isolated 25 cultivable bacteria with extracellular protease activity from sediments associated with two deepsea hydrothermal vents in Okinawa Trough, which belong to 9 different genera (Bacillus, Exiguobacterium, Fictibacillus, Alteromonas, Brevibacterium, Rheinheimera, Marinomonas, Halomonas and Pseudoalteromonas) (Sun et al., 2015). Genome sequence analysis revealed that Caloranaerobacter sp. TR13, isolated from a deep-sea hydrothermal vent on the East Pacific Rise, could encode 40 peptidases and 26 proteases including 2 subtilisin-like serine proteases, and another strain Lutibacter profundi $\mathrm{LP}^{\mathrm{T}}$, isolated from an Arctic deep-sea hydrothermal vent system, could encode 130 proteases (Zhou et al., 2015; Wissuwa et al., 2017). In addition, an M1 family aminopeptidase from Pseudoalteromonas telluritireducens DSM 16098, a strain isolated from deep-sea hydrothermal vents fluid, was cloned and characterized, which suggests that the extracellular aminopeptidase from Pseudoalteromonas executes the degradation of organic matters in deep-sea hydrothermal vent ecosystem (Zhang et al., 2018). These studies suggest that protease-secreting bacteria in hydrothermal vents should be actively involved in decomposing dissolved and particulate organic nitrogen, and thus play important roles in marine biogeochemical cycling. Despite these studies, as far as we know, there has been no report on protease-secreting Anoxybacillus from deep-sea hydrothermal vent ecosystem, although several Anoxybacillus strains from terrestrial hot spring have been reported to secrete extracellular proteases.

In this study, we investigated the bacterial strain A. caldiproteolyticus 1A02591 from a deep-sea hydrothermal vent sediment of the East Pacific Ocean. Further analysis showed that strain 1A02591 is a thermophilic bacterium and has a strong protease-secreting ability. The optimum temperature for its growth and extracellular protease production was $55^{\circ} \mathrm{C}$. We characterized the extracellular proteases of strain 1A02591, and described the diversity and functions of the extracellular and intracellular proteases of this thermophilic strain by analysis of the genome sequencing, gene annotation and secretome analysis. The extracellular proteases of strain 1A02591 cultured with casein had the highest activity at the temperature as high as $70^{\circ} \mathrm{C}$, indicating that thermophilic proteases are secreted by strain 1A02591. The extracellular proteases of strain 1A02591 could degrade different kinds of proteins including casein, gelatin and collagen. The extracellular proteases of strain 1A02591 was inhibited $70 \%$ by metalloprotease inhibitor $o$-phenanthroline and $50 \%$ by serine protease inhibitor PMSF, indicating that the extracellular proteases include both metalloprotease(s) and serine protease(s). Consistent with this, secretome analysis showed that metalloproteases from families M3, M4, M20, M23, and M32 and serine proteases from families S8, S11, and S41 accounted for the majority of the extracellular proteases. These secreted metalloproteases and serine proteases enable strain $1 \mathrm{~A} 02591$ to actively degrade various exterior proteins, which provides carbon and nitrogen nutrients for itself and potentially other neighboring microorganisms, and promotes the carbon and nitrogen recycling in the deep-sea hydrothermal vent ecosystem. Thus, protease-secreting Anoxybacillus may play a role in the deep-sea biogeochemical cycle.

According to secretome analysis, the most abundant protease secreted by strain $1 \mathrm{~A} 02591$ is a thermolysin-like protease. Thermolysin (EC 3.4.24.27) is a thermostable neutral zinc metalloproteinase produced by Bacillus thermoproteolyticus, which is the prototype of the M4 family (Yasukawa et al., 2007). Thermolysin contains 316 amino acid residues and requires one zinc ion for enzyme activity and four calciumions for structural stability (Latt, 1969; Feder et al., 1971; Titani et al., 1972). Thermolysin has been used in the production of the artificial sweetener aspartame (Birrane et al., 2014), and widely used as a non-specific proteinase to obtain fragments for peptide sequencing (Seidah et al., 1982). Thermolysin has also been used as an additive of liquid detergent due to its thermostability (Estell et al., 2019). A lot of thermolysin-like proteases have been reported, which all contain a similar catalytic domain as thermolysin (Jin et al., 1996; Tang et al., 2003). The thermolysinlike protease of strain 1A02591 shares $98.82 \%$ sequence similarity with thermolysin. It is most likely a thermostable protease based on the characters of the extracellular proteases secreted by strain 1A02591. The other biochemical characters of this thermolysinlike protease need further study.

Thermophilic proteases have various biotechnological and industrial applications. For instance, thermophilic proteases can be used as a protein degrader in waste treatment processes, e.g., the solubilization of sewage sludge (Nakamichi et al., 2010; Kun et al., 2018). They also can be used as the detergents in high-temperature conditions (Mechri et al., 2019; Emran et al., 2020). The results in this study indicate that Anoxybacillus strain $1 \mathrm{~A} 02591$ is likely to be developed as a good producer of thermophilic proteases that may have various biotechnological applications. Especially, the extracellular proteases of strain $1 \mathrm{~A} 02591$ has high activity on bovine insoluble type I collagen, implying that they may have a potential in preparing oligopeptides from collagen. Therefore, the application potentials of strain 1A02591 and its extracelluar thermophilic proteases deserve to be further studied. 


\section{DATA AVAILABILITY STATEMENT}

The datasets presented in this study can be found in online repositories. The names of the repository/repositories and accession number(s) can be found below https://www.ncbi. nlm.nih.gov/genbank/, JAEILW000000000, http://www.proteo mexchange.org/, PXD023396.

\section{AUTHOR CONTRIBUTIONS}

Y-ZZ and X-LC designed the research. X-LC and YZ directed the research. J-HC, YW, and X-YZ performed the experiments. M-LS and XZ helped in data analysis. J-HC wrote the manuscript. $\mathrm{X}$-LC and X-YS edited the manuscript. All authors read and approved the manuscript.

\section{FUNDING}

This work was supported by the National Key R\&D Program of China (2018YFC0310704 and 2018YFC1406504, awarded to X-LC and X-YS, respectively), the National Science Foundation of China (grants U2006205, U1706207, and 41906195, awarded to X-LC, Y-ZZ, and YZ, respectively),

\section{REFERENCES}

Baranyi, J., and Roberts, T. A. (1994). A dynamic approach to predicting bacterial growth in food. Int. J. Food Microbiol. 23, 277-294. doi: 10.1016/0168-1605(94) 90157-0

Barrett, A. J., Rawlings, N. D., and O'Brien, E. A. (2001). The MEROPS database as a protease information system. J. Struct. Biol. 134, 95-102. doi: 10.1006/jsbi. 2000.4332

Bekler, F. M., Pirinççioğlu, H., Güven, R. G., Güven, K., and Acer, Ö (2016). Purification and characterization of thermostable and detergent-stable $\alpha$ amylase from Anoxybacillus sp. AH1. Food Technol. Biotechnol. 54, 70-77. doi: $10.17133 / \mathrm{ftb} .54 .01 .16 .4122$

Bendtsen, J. D., Nielsen, H., Heijne, G. G. V., and Brunak, S. S. (2004). Improved prediction of signal peptides: SignalP 3.0. J. Mol. Biol. 340, 783-795. doi: 10. 1016/j.jmb.2004.05.028

Birrane, G., Bhyravbhatla, B., and Navia, M. A. (2014). Synthesis of aspartame by thermolysin: an X-ray structural study. ACS Med. Chem. Lett. 5, 706-710. doi: $10.1021 / \mathrm{ml} 500101 \mathrm{z}$

Burrell, T. J., Maas, E. W., Hulston, D. A., Law, C. S., and Zhang, Y. Z. (2015). Bacterial abundance, processes and diversity responses to acidification at a coastal $\mathrm{CO}_{2}$ vent. FEMS Microbiol. Lett. 362:fnv154. doi: 10.1093/femsle/ fnv154

Chaberek, S., Courtney, R. C., and Martell, A. E. (1952). Stability of metal chelates. II. $\beta$-hydroxyethyliminodiacetic acid. J. Am. Chem. Soc. 74, 5057-5060. doi: 10.1021/ja01140a019

Chen, X. L., Zhang, Y. Z., Gao, P. J., and Luan, X. W. (2003). Two different proteases produced by a deep-sea psychrotrophic bacterial strain, Pseudoaltermonas sp. SM9913. Mar. Biol. 143, 989-993. doi: 10.1007/s00227003-1128-2

Delcher, A. L., Bratke, K. A., Powers, E. C., and Salzberg, L. S. (2007). Identifying bacterial genes and endosymbiont DNA with Glimmer. Bioinformatics 23, 673-679. doi: 10.1093/bioinformatics/btm009

Dey, A., Bokka, V., and Sen, S. (2020). Dependence of bacterial growth rate on dynamic temperature changes. IET Syst. Biol. 14, 68-74. doi: 10.1049/iet-syb. 2018.5125 the Major Scientific and Technological Innovation Project (MSTIP) of Shandong Province (2019JZZY010817 awarded to Y-ZZ), Taishan Scholars Program of Shandong Province (tspd20181203, awarded to Y-ZZ), and Development of Marine Economy Demonstration City Program during the 13th FiveYear Plan Period-Preparation of active marine Protein feed additives and construction of industrial chain (awarded to Y-ZZ).

\section{ACKNOWLEDGMENTS}

The authors thank Dr. Lingwei Ruan of Third Institute of Oceanography for providing the sample collection information, and thank Zhifeng Li, Jingyao Qu and Jing Zhu from the State Key Laboratory of Microbial Technology of Shandong University for their help and guidance in secretome analysis.

\section{SUPPLEMENTARY MATERIAL}

The Supplementary Material for this article can be found online at: https://www.frontiersin.org/articles/10.3389/fmicb. 2021.643508/full\#supplementary-material

Dong, T. C., and Cutting, S. M. (2004). The PDZ domain of the SpoIVB transmembrane signaling protein enables cis-trans interactions involving multiple partners leading to the activation of the pro-sigmaK processing complex in Bacillus subtilis. J. Biol. Chem. 279, 43468-43478. doi: 10.1074/jbc. M407048200

Edwards, D. B., and Nelson, D. C. (1991). DNA-DNA solution hybridization studies of the bacterial symbionts of hydrothermal vent tube worms (Riftia pachyptila and Tevnia jerichonana). Appl. Environ. Microbiol. 57, 1082-1088. doi: 10.1128/AEM.57.4.1082-1088.1991

Emran, M. A., Ismail, S. A., and Hashem, A. M. (2020). Production of detergent stable thermophilic alkaline protease by Bacillus licheniformis ALW1. Biocatal. Agric. Biotechnol. 26:101631. doi: 10.1016/j.bcab.2020.101631

Estell, D. A., Liu, A. D., Hommes, R. W. J., and Shaw, A. (2019). Production of thermolysin and variants thereof, and use in liquid detergents*. European Patent No 2,845,900.

Feder, J., Garrett, L. R., and Wildi, B. S. (1971). Studies on the role of calcium in thermolysin. Biochemistry 10, 4552-4556. doi: 10.1021/bi00800a032

Fukushima, T., Uchida, N., Ide, M., Kodama, T., and Sekiguchi, J. (2018). DL-endopeptidases function as both cell wall hydrolases and poly-gammaglutamic acid hydrolases. Microbiology 164, 277-286. doi: 10.1099/mic.0.00 0609

Gottesman, S. (1996). Proteases and their targets in Escherichia coli. Annu. Rev. Genet. 30, 465-506. doi: 10.1146/annurev.genet.30.1.465

Guven, K., Acer, O., Bekler, F., et al. (2015). Production and purification of novel thermostable alkaline protease from Anoxybacillus sp. KP1. Cell Mol. Biol. 61, 113-120. doi: $10.14715 / \mathrm{cmb} / 2015.61 .4 .18$

Hajiabadi, S., Mashreghi, M., Bahrami, A. R., Ghazvini, K., and Matin, M. M. (2019). Isolation and molecular identification of cellulolytic bacteria from Dig Rostam hot spring and study of their cellulase activity. Biocell 43, 63-71. doi: 10.32604/biocell.2020.08171

Jackman, S. D., Vandervalk, B. P., Mohamadi, H., Chu, J., Yeo, S., Hammond, S. A., et al. (2017). ABySS 2.0: resource-efficient assembly of large genomes using a Bloom filter. Genome Res. 27, 768-777. doi: 10.1101/gr.214346.116

Jin, F. U., Matsushita, O., Katayama, S. I., Jin, S., and Okabe, A. (1996). Purification, characterization, and primary structure of Clostridium perfringens 
lambda-toxin, a thermolysin-like metalloprotease. Infect. Immun. 64, 230-237. doi: 10.1128/IAI.64.1.230-237.1996

Junne, S., Klingner, A., Kabisch, J., Schweder, T., and Neubauer, P. (2011). A twocompartment bioreactor system made of commercial parts for bioprocess scaledown studies: impact of oscillations on Bacillus subtilis fed-batch cultivations. Biotechnol. J. 6, 1009-1017. doi: 10.1002/biot.201100293

Karched, M., Bhardwaj, R. G., Tiss, A., and Asikainen, S. (2019). Proteomic analysis and virulence assessment of Granulicatella adiacens secretome. Front. Cell Infect. Microbiol. 9:104. doi: 10.3389/fcimb.2019.00104

Karin, L., Peter, H., Andreas, R. E., Hans-Henrik, S., Torbjørn, R., and Ussery, D. W. (2007). RNAmmer: consistent and rapid annotation of ribosomal RNA genes. Nucleic Acids Res. 35, 3100-3108. doi: 10.1093/nar/gkm160

Kim, S. J., Pak, S. J., and Ju, S. J. (2015). Mitochondrial genome of the hydrothermal vent shrimp Nautilocaris saintlaurentae (Crustacea: Caridea:Alvinocarididae). Mitochondrial DNA 26, 127-128. doi: 10.3109/19401736.2013.815169

Kun, L., Xiao, X., Qi, Y., Fei, C., Yu, Z., Pin, X., et al. (2018). Multi-hydrolytic enzyme accumulation and microbial community structure of anaerobic codigestion of food waste and waste-activated sludge. Environ. Technol. 41, 478-487. doi: 10.1080/09593330.2018.1502364

Ladrat, C., Cornec, L., Alayse-Danet, A. M., and Barbier, G. (1995). Demonstration of thermostable enzymes in thermophilic micro-organisms of hydrothermal origin. C. R. Acad. Sci. 318, 423-429.

Laskar, A., Rodger, E. J., Chatterjee, A., and Mandal, C. (2012). Modeling and structural analysis of PA clan serine proteases. BMC Res. Notes. 5, 1-11. doi: 10.1186/1756-0500-5-256

Latt, S. A. (1969). Thermolysin: a zinc metalloenzyme. Biochem. Biophys. Res. Commun. 37, 333-339. doi: 10.1016/0006-291x(69)90739-6

Lavrenteva, E. V., Shagzhina, A. P., Babasanova, O. B., Dunaevsky, Y. E., Namsaraev, Z. B., and Barkhutova, D. D. (2009). The study of two alkaliphilic thermophile bacteria of the Anoxybacillus genus as producers of extracellular proteinase. Prikl. Biokhim. Mikrobiol. 45, 538-543. doi: 10.1134/ S0003683809050044

Le Moine Bauer, S., Roalkvam, I., Steen, I. H., and Dahle, H. (2016). Lutibacter profundi sp. nov., isolated from a deep-sea hydrothermal system on the Arctic Mid-Ocean Ridge and emended description of the genus Lutibacter. Int. J. Syst. Evol. Microbiol. 66, 2671-2677. doi: 10.1099/ijsem.0.001105

Li, H. J., Tang, B. L., Shao, X., Liu, B. X., Zheng, X. Y., Han, X. X., et al. (2016). Characterization of a new $S 8$ serine protease from marine sedimentary Photobacterium sp. A5-7 and the function of its protease-associated domain. Front. Microbiol. 7:2016. doi: 10.3389/fmicb.2016.02016

Lowe, T. M., and Eddy, S. R. (1997). tRNAscan-SE: a program for improved detection of transferRNA genes in genomic sequence. Nucleic Acids Res. 25, 955-964. doi: 10.1093/nar/25.5.955

Mechri, S., Bouacem, K., Zarai Jaouadi, N., Rekik, H., Ben Elhoul, M., Omrane Benmrad, M., et al. (2019). Identification of a novel protease from the thermophilic Anoxybacillus kamchatkensis M1V and its application as laundry detergent additive. Extremophiles 23, 687-706. doi: 10.1007/s00792-01901123-6

Meng, L., Sunit, J., and Dick, G. J. (2016). Genomic and transcriptomic resolution of organic matter utilization among deep-sea bacteria in Guaymas Basin hydrothermal plumes. Front. Microbiol. 7:1125. doi: 10.3389/fmicb.2016. 01125

Minoru, K., Yoko, S., Masayuki, K., Miho, F., and Mao, T. (2016). KEGG as a reference resource for gene and protein annotation. Nucleic Acids Res. 44, D457-D462. doi: 10.1093/nar/gkv1070

Nakamichi, T., Nakashima, T., Fujisaki, H., Takamatsu, N., Muramatsu, T., Takahashi, Y., et al. (2010). Characteristics of Anoxybacillus sp. MU3 isolated from a hot spring and its application to the hyper thermal solubilization of sewage sludge. Environ. Eng. sci. 27, 993-999. doi: 10.1089/ees.2010.0077

Pikuta, E., Lysenko, A., Chuvilskaya, N., Mendrock, U., Hippe, H., Suzina, N., et al. (2000). Anoxybacillus pushchinensis gen. nov., sp. nov., a novel anaerobic, alkaliphilic, moderately thermophilic bacterium from manure, and description of Anoxybacillus flavitherms comb. nov. Int. J. Syst. Evol. Microbiol. 50, 21092117. doi: 10.1099/00207713-50-6-2109

Pikuta, E. V., Marsic, D., Itoh, T., Bej, A. K., Tang, J., Whitman, W. B., et al. (2007). Thermococcus thioreducens sp. nov., a novel hyperthermophilic, obligately sulfur-reducing archaeon from a deep-sea hydrothermal vent. Int. J. Syst. Evol. Microbiol. 57, 1612-1618. doi: 10.1099/ijs.0.65057-0
Plouviez, S., Faure, B., Le Guen, D., Lallier, F. H., Bierne, N., and Jollivet, D. (2013). A new barrier to dispersal trapped old genetic clines that escaped the Easter Microplate tension zone of the Pacific vent mussels. PLoS One 8:e81555. doi: 10.1371/journal.pone.0081555

Punam, Y., Jyoti, M., Suresh, K., Prasad, G. S., Girish, S., Tribikram, B., et al. (2018). Production, purification, and characterization of thermostable alkaline xylanase from Anoxybacillus kamchatkensis NASTPD13. Front. Bioeng. Biotechnol. 6:65. doi: $10.3389 /$ fbioe.2018.00065

Rajasabapathy, R., Mohandass, C., Yoon, J. H., Dastager, S. G., Liu, Q., Khieu, T. N., et al. (2015). Vitellibacter nionensis sp. nov., isolated from a shallow water hydrothermal vent. Int. J. Syst. Evol. Microbiol. 65(Pt 2), 692-697. doi: 10.1099/ijs.0.070805-0

Ran, L. Y., Su, H. N., Zhao, G. Y., Gao, X., Zhou, M. Y., Wang, P., et al. (2013). Structural and mechanistic insights into collagen degradation by a bacterial collagenolytic serine protease in the subtilisin family. Mol. Microbiol. 90, 997-1010. doi: 10.1111/mmi.12412

Ran, L. Y., Su, H. N., Zhou, M. Y., Wang, L., Chen, X. L., Xie, B. B., et al. (2014). Characterization of a novel subtilisin-like protease myroicolsin from deep sea bacterium Myroides profundi D25 and molecular insight into its collagenolytic mechanism. J. Biol. Chem. 289, 6041-6053. doi: 10.1074/jbc.M113. 513861

Rawlings, N. D., Morton, F. R., Yin, K. C., Jun, K., and Barrett, A. J. (2008). MEROPS: the peptidase database. Nucleic Acids Res. 36, D320-D325. doi: 10. 1093/nar/gkm954

Rawlings, N. D., Barrett, A. J., Thomas, P. D., Xiaosong, H., Alex, B., and Finn, R. D. (2017). The MEROPS database of proteolytic enzymes, their substrates and inhibitors in 2017 and a comparison with peptidases in the PANTHER database. Nucleic Acids Res. 46, D624-D632. doi: 10.1093/nar/ gkx1134

Sachar, L. A., Winter, K. K., Sicher, N., and Frankel, S. (1955). Photometric method for estimation of elastase activity. Proc. Soc. Exp. Biol. Med. 90, 323-326. doi: 10.3181/00379727-90-22022

Seidah, N. G., Hsi, K. L., Chrétien, M., Barat, E., Patthy, A., and Graf, L. (1982). The primary structure of human beta-lipotropin. Further peptide sequencing resolves the controversy and suggests the existence of only one human beta-lipotropin. FEBS Lett. 147, 267-272. doi: 10.1016/0014-5793(82)81 056-9

Sun, Q. L., Wang, M. Q., and Sun, L. (2015). Characteristics of the cultivable bacteria from sediments associated with two deep-sea hydrothermal vents in Okinawa Trough. World J. Microbiol. Biotechnol. 31, 2025-2037. doi: 10.1007/ s11274-015-1953-8

Tang, B., Nirasawa, S., Kitaoka, M., Marie-Claire, C., and Hayashi, K. (2003). General function of N-terminal propeptide on assisting protein folding and inhibiting catalytic activity based on observations with a chimeric thermolysinlike protease. Biochem. Biophys. Res. Commun. 301, 1093-1098. doi: 10.1016/ s0006-291x(03)00084-6

Tang, B. L., Yang, J., Chen, X. L., Wang, P., Zhao, H. L., Su, H. N., et al. (2020). A predator-prey interaction between a marine Pseudoalteromonas sp. and Gram-positive bacteria. Nat. Commun. 11:285. doi: 10.1038/s41467-019-14 $133-\mathrm{x}$

Tatusov, R. L., Galperin, M. Y., Natale, D. A., and Koonin, E. V. (2000). The COG database: a tool for genome-scale analysis of protein functions and evolution. Nucleic Acids Res. 28, 33-36. doi: 10.1093/nar/28.1.33

Titani, K., Hermodson, M. A., Ericsson, L. H., Walsh, K. A., and Neurath, H. (1972). Amino-acid sequence of thermolysin. Nat. N. Biol. 238, 35-37. doi: 10.1038/newbio238035a0

Wang, Y., Liu, B. X., Cheng, J. H., Su, H. N., Sun, H. M., Li, C. Y., et al. (2020). Characterization of a new M4 metalloprotease with collagen-swelling ability from marine Vibrio pomeroyi strain 12613. Front. Microbiol. 11:1868. doi: 10. 3389/fmicb.2020.01868

Wissuwa, J., Bauer, S. L., Steen, I. H., and Stokke, R. (2017). Complete genome sequence of Lutibacter profundi LP1(T) isolated from an Arctic deep-sea hydrothermal vent system. Stand Genomic Sci. 12:5. doi: 10.1186/s40793-0160219-x

Yasukawa, K., Kusano, M., and Inouye, K. (2007). A new method for the extracellular production of recombinant thermolysin by co-expressing the mature sequence and pro-sequence in Escherichia coli. Protein Eng. Des. Sel. 20, 375-383. doi: 10.1093/protein/gzm031 
Zhang, H., Wang, H., Liu, R., Wang, L., and Song, L. (2018). Cloning and characterization of a leucine aminopeptidase from Pseudoalteromonas telluritireducens DSM 16098, a strain isolated from hydrothermal vents fluid. Deep-sea Res. Pt. I 138, 114-121. doi: 10.1016/j.dsr.2018. 06.006

Zhao, X., Cai, M., Yang, Z. J., Luo, T. Q., Sarwar, A., Megrous, S., et al. (2019). Purification and characterization of a novel milkclotting enzyme produced by Bacillus amyloliquefaciens GSBa-1. Eur. Food Res. Technol. 245, 2447-2457. doi: 10.1007/s00217-019-03361-6

Zhou, M., Xie, Y., Dong, B., Liu, Q., and Chen, X. (2015). Draft genome sequence of Caloranaerobacter sp. TR13, an anaerobic thermophilic bacterium isolated from a deep-sea hydrothermal vent. Genome Announc. 3, e1491-e1415. doi: 10.1128/genomeA.01491-15
Conflict of Interest: XZ was employed by the company Qingdao Vland Biotech Inc.

The remaining authors declare that the research was conducted in the absence of any commercial or financial relationships that could be construed as a potential conflict of interest.

Copyright (c) 2021 Cheng, Wang, Zhang, Sun, Zhang, Song, Zhang, Zhang and Chen. This is an open-access article distributed under the terms of the Creative Commons Attribution License (CC BY). The use, distribution or reproduction in other forums is permitted, provided the original author(s) and the copyright owner(s) are credited and that the original publication in this journal is cited, in accordance with accepted academic practice. No use, distribution or reproduction is permitted which does not comply with these terms. 